\title{
Molecular characterization of Cryptosporidium in calves from rural settlements in the Northwest region of the state of São Paulo, Brazil
}

\author{
Caracterização molecular de Cryptosporidium em bezerros de \\ assentamentos rurais da região Noroeste do estado de São Paulo, \\ Brasil
}

\author{
Lucas Vinicius Shigaki de Matos ${ }^{1 *}$; Luiz da Silveira Neto²; Bruno César Miranda \\ Oliveira $^{3}$; Miriam Yumi Makatu ${ }^{3}$; Julia Cestari Pierucci ${ }^{1}$; Milena Araúz Viol' \\ Jancarlo Ferreira Gomes ${ }^{4}$; Gilson Pereira de Oliveira ${ }^{5}$; Giovanni Widmer ${ }^{6}$; Katia \\ Denise Saraiva Bresciani ${ }^{7}$
}

\begin{abstract}
The study was conducted on 25 properties of the settlements São José I and Salvador, located in the municipalities of Brejo Alegre and Birigui, in the State of São Paulo, Brazil. A record of variables was elaborated and included data such as gender, breed and age of the animals. A total of 231 stool samples were collected from bovines aged one to six months, 128 being females and 103 males, 131 crossbred and 100 Holstein. Among the 231 samples, 17 (7.36\%) were positive for Cryptosporidium spp. both by malachite green negative staining and by nested-PCR. Of the 17 positive samples, 14 were sequenced in agarose gel. These sequences were detected between $99 \%$ and $100 \%$ of genetic similarity for the following species. One sequence was similar to C. parvum (AB513880.1), one to C. bovis (MF074602.1), two to C. ryanae (KT922233.1), one to C. felis (KM977642.1) and nine were similar for C. andersoni reference MF350628. C. andersoni was found in animals aged 2-6 months, an age group which is different from those described by several authors. The presence of C. parvum indicates that the calves in the studied region should be considered a potential source for zoonotic transmission. For the first time to our knowledge, C. felis was identified in cattle in America.
\end{abstract}

Key words: Calves. Cryptosporidiosis. Molecular characterization. Nested-PCR.

\section{Resumo}

O estudo foi realizado num total de 25 propriedades localizadas nos assentamentos São José I e Salvador, situados nos municípios de Brejo Alegre e Birigui, no estado de São Paulo. Um registro de variáveis foi elaborado, incluindo dados como sexo, raça e idade dos animais. Foram colhidas 231 amostras de fezes

\footnotetext{
Discentes, Universidade Estadual Paulista, UNESP, Faculdade de Ciências Agrárias e Veterinárias, Jaboticabal, SP, Brasil. E-mail: lucasvsm@hotmail.com; juliacpierucci@hotmail.com

2 Prof., Universidade Federal do Tocantins, UFT, Gurupi, TO, Brasil. E-mail: luiz.silveira@uft.edu.br

3 Discentes, UNESP, Faculdade de Medicina Veterinária de Araçatuba, Araçatuba, SP, Brasil. E-mail: bruno.miranda_oliveira@ tufts.edu; yumi_jpbr@hotmail.com; milenaviol@hotmail.com

4 Prof., Universidade Estadual de Campinas, UNICAMP, Campinas, SP, Brasil. E-mail: jgomes@ic.unicamp.br

5 Prof., UNESP, Faculdade de Ciências Agrárias e Veterinárias, Jaboticabal, SP, Brasil. E-mail: gilsongpod@fcav.unesp.br

6 Prof., Cummings School of Veterinary Medicine at Tufts University, North Grafton, Massachusetts, 01536, USA. E-mail: giovanni.widmer@tufts.edu

Prof ${ }^{a}$, UNESP, Faculdade de Medicina Veterinária de Araçatuba, Araçatuba, SP, Brasil. E-mail: bresciani@fmva.unesp.br

* Author for correspondence
} 
de bovinos de um a seis meses de idade, sendo 128 fêmeas e 103 machos, 131 mestiços e 100 da raça Holandesa. Entre os 231 bovinos examinados, 17 (7,36\%) foram positivos para Cryptosporidium spp. tanto pela coloração negativa de verde malaquita como pela nested-PCR. Das 17 amostras positivas, 14 apresentaram amplificação pela eletroforese em gel de agarose suficiente para fazer o sequenciamento de DNA. Essas sequências foram detectadas similaridade genética entre $99 \%$ e $100 \%$ com as seguintes espécies. Uma sequência foi semelhante com C. parvum (referência: AB513880.1), uma com C. bovis (MF074602.1), duas com C. ryanae (KT922233.1), uma com C. felis (KM977642.1) e nove foram semelhantes com C. andersoni (MF350628). O estudo caracteriza a presença do Cryptosporidium spp. em bovinos oriundos de propriedades produtoras de leite na região Noroeste do estado de São Paulo, sendo o $C$. andersoni a espécie mais prevalente nesses animais, principalmente em uma faixa etária diferente das descritas por diversos autores. A presença de C. parvum indica que os bezerros da região estudada devem ser considerados como uma fonte potencial de oocistos de espécies zoonóticas. Identificamos com ineditismo o C. felis em bovinos na América, o que corrobora outros estudos realizados na Polônia e Espanha e evidencia a presença de espécies de Cryptosporidium em fezes em hospedeiros não naturais.

Palavras-chave: Bezerros. Caracterização molecular. Criptosporidiose. Nested-PCR.

Protozoan of the genus Cryptosporidium are obligate intracellular coccidia with a cosmopolitan distribution. Biological data and various molecular genotyping tools indicate that the genus Cryptosporidium comprises about 30 valid species and more than 70 genotypes that can infect fishes, amphibians, reptiles, birds, and mammals (NAKAMURA; MEIRELES, 2015).

Among the named species, 13 have been described in cattle. Of these, nine present zoonotic potential, being more prevalent in humans: Cryptosporidium hominis, Cryptosporidium parvum, Cryptosporidium meleagridis, Cryptosporidium cuniculus and, occasionally, Cryptosporidium muris, Cryptosporidium suis, Cryptosporidium ubiquitum, Cryptosporidium felis (BORNAY-LLINARES et al. 1999; CARDONA et al., 2015) and Cryptosporidium canis (KVÁČ et al., 2016).

Cattle are mainly infected with $C$. parvum, Cryptosporidium bovis, Cryptosporidium ryanae and Cryptosporidium andersoni (XIAO, 2010). Of these, only the first is of zoonotic importance, being a concern for public health, since human cryptosporidiosis can be acquired from infected calves (LEARMONTH et al., 2004; SOPWITH et al., 2005; DEL COCO et al., 2014). These four species of Cryptosporidium are frequently diagnosed in cattle of different ages. Among these, C. parvum is the most prevalent in young pre-weaning calves (less than two months old) and shows low host specificity, and some genotypes are considered to have high zoonotic potential (DIXON et al., 2011).

During the post-weaning phase (three to 11 months of age) a reduction in the prevalence of C. parvum is observed, however, in this stage an increase of $C$. bovis and C. ryanae infections is noticed. The latter two species are not considered zoonotic and show high specificity for bovine. $C$. andersoni is the species that mainly infects postweaned calves and adult cattle. These parasitic species can infect other ruminants and rarely humans (DIXON et al., 2011).

Due to the ability of this protozoan to infect different hosts and its constant presence in the environment, humans can acquire the infection in several ways, such as through ingestion of food and water contaminated with oocysts, direct contact with infected people (anthroponotic) or animals (zoonotic). Increases in environmental contamination and infected reservoirs assist in zoonotic transmission, as human cryptosporidiosis is also caused by certain species that also affect ruminants. The contact of humans with the feces of these animals that contains oocysts or contaminated water constitutes routes of transmission to humans (DEL COCO et al., 2014). 
The study was conducted in 25 properties of the settlements São José I and Salvador, located in the municipalities of Brejo Alegre and Birigui, in the State of São Paulo (Latitude 21.166062, Longitude 50.186433) (MAKATU et al., 2017). A record of variables was elaborated and included data such as gender, breed and age of the animals. The protocol number of the ethics committee was 2014-00593.

A total of 231 stool samples were collected from bovines aged one to six months, 128 being females and 103 males, 131 crossbred and 100 Holstein.

The samples containing $2,5 \%$ potassium dichromate were filtered in disposable plastic tampons containing an eight-layer gauze, and the contents were transferred to $50 \mathrm{ml}$ conical test tubes, with water added with $1 \%$ Tween 80 to $32.5 \mathrm{~mL}$ and next an amount of $40 \mathrm{~mL}$ of petroleum-ether PA was added. After homogenization, centrifugation was done at 2,000 $\mathrm{g}$ for eight minutes. Next, the supernatant was discarded, and $15 \mathrm{~mL}$ of the Tween 80 water solution was added and centrifugated at $1,000 \mathrm{~g}$ for five minutes. This step was repeated twice more until the supernatant was clear. The supernatant was discarded. A volume of $25 \mu \mathrm{L}$ of pellet and $25 \mu \mathrm{L}$ of $5 \%$ malachite green were homogenized and transferred to a slide. The reading was performed in a light microscope with a $40 \mathrm{x}$ objective (ELLIOT et al., 1999).

After purification of the fecal samples in order to concentrate the oocysts, DNA was extracted using the QIAamp ${ }^{\circledR}$ DNA Stool Mini Kit (Qiagen), following the protocol described by the manufacturer. Extracted DNA was stored at $-20^{\circ} \mathrm{C}$ until nested PCR (nPCR) was performed to amplify an approximately 800-bp fragment of the $18 \mathrm{~S}$ subunit ribosomal RNA gene (XIAO et al., 2000). Genomic DNA of Cryptosporidium serpentis and ultrapure water were used as positive and negative controls, respectively.

Amplicons obtained by nPCR were purified using the QIAquick Gel Extraction Kit (Qiagen) and sequenced using the ABI PRISM Big Dye
Terminator Cycle Sequencing Ready Reaction Kit (Applied Biosystems) in an ABI 3730 XL automatic sequencer (Applied Biosystems, USA). The amplicons were sequenced with both primers (forward and reverse) used in nPCR reaction. The CodonCode Aligner version 5.1.5 program (CodonCode Corporation, Dedham, MA, USA) was used to determine the consensus sequences, which were aligned to the homologous sequences downloaded from GenBank with Clustal W (THOMPSON et al., 1997).

Among the 231 cattle examined, 17 (7.36\%) were positive for Cryptosporidium spp. both by malachite green negative staining and by nPCR.

Of the 17 positive samples, 14 were sequenced in agarose gel. These sequences were detected between $99 \%$ and $100 \%$ of genetic similarity for the following species. The nucleotide sequences generated in this study were deposited in GenBank under accession numbers MH458438 to MH458443. One sequence was similar to C. parvum (AB513880.1), one to C. bovis (MF074602.1), two to C. ryanae (KT922233.1), one to C. felis (KM977642.1) and nine were similar for $C$. andersoni reference MF350628.1 (Table 1).

Among the 25 dairies of this study, in six of them (24\%), all located in São José I settlement, calves infected with Cryptosporidium spp. were found.

Four males and two females were positive in the property where the highest occurrence of Cryptosporidium spp. was observed, five of which eliminated oocysts of $C$. andersoni and one $C$. ryanae, and all these animals were over 30 days old. In all of the properties the calves were kept in the same pasture and were only taken to their respective mothers at the moment of milking, when they were breastfed only long enough to stimulate milk letdown and then were separated.

In the present study, $C$. bovis was identified in one animal between 31 and 60 days of age and $C$. ryanae infected two animals, one between 31 and 60 days and the other between 61 and 120 days. 
Considering only the 17 positive animals for $(52.94 \%$; 9/17). Of these, eight were aged between Cryptosporidium in our study, we detected a high 121 and 180 days and one animal had between 61 prevalence of positive animals for $C$. andersoni and 120 days.

Table 1. Identification of Cryptosporidium spp. species by PCR, according to the age range of the animals.

\begin{tabular}{cccl}
\hline Age group (days) & N & Positive-PCR \% & \multicolumn{1}{c}{ Species Identification $^{\mathbf{a}}$} \\
\hline $0-30$ & 1 & $1(5.88 \%)$ & C. parvum (1) \\
$31-60$ & 3 & $3(17.65 \%)$ & C. ryanae (1), Cryptosporidium spp. (1), C. bovis (1) \\
$61-120$ & 5 & $5(29.41 \%)$ & Cryptosporidium spp. (2), C. felis (1), C. ryanae (1), C. andersoni (1) \\
$121-180$ & 8 & $8(47.06 \%)$ & $\begin{array}{l}\text { C. andersoni (8) } \\
\text { Total }\end{array}$ \\
\hline
\end{tabular}

a - Species identification was performed only with samples that showed intense DNA amplification.

Our study represents the first identification of $C$. felis in calves in the Americas (BORNAYLLINARES et al., 1999, CARDONA et al., 2015; KVÁČ et al., 2016). Although several Cryptosporidium species have been reported in cattle using molecular techniques (OUAKLI et al., 2018), C. felis has been identified only twice in cattle in Europe (BORNAY-LLINARES et al., 1999, CARDONA et al. al., 2015), and in America, with our finding. In Poland (BORNAY-LLINARES et al., 1999) and in Spain (CARDONA et al., 2015), C. felis was observed in adult cows with the use of molecular techniques (PCR), although no clinical signs were observed as a result of this infection.

Detection of $C$. felis in bovine fecal samples could mean that these animals are infected or act as passive carriers of this protozoan oocyst. Regardless of the situation, contamination of fodder or water with faecal material of cats that contains C. felis seems to be the most plausible explanation for the presence of this species in cattle (CARDONA et al., 2015).

The bovine positive to $C$. felis was a mixedbreed female of three months of age and presented feces with a watery consistency. Analyzing the questionnaire, this animal belonged to a property in which a domestic cat dwelled. Fifteen other properties had cats, but no positivity was found for C. felis in cattle.

The results of $C$. bovis and C. ryanae corroborate the review of 16 papers of Gong et al. (2017) who performed molecular methods. The authors concluded that $C$. ryanae affects animals from birth through eight weeks of life; however, C. bovis can also affect animals of 12 weeks old (SANTÍN et al., 2004). In contrast, the animal infected with $C$. ryanae in our study was aged between 61 and 120 days, similar situation to that found in studies of Santín et al. (2004) and Santín et al. (2008) that used 18S PCR and molecular characterization and detected $C$. ryanae in animals older than three months of age.

In epidemiological surveys conducted in China, India, Poland and Ethiopia, the average prevalence of Cryptosporidium spp. in young calves ranged from $5.6 \%$ to $17 \%$ (WANG et al., 2014; WEGAYEHU et al., 2016).

In the present study, out of 231 animals, only one was infected with C. parvum. This low prevalence can be due to the fact that only two animals $(0.87 \%)$ aging less than one month participated in the study, since it is known that this protozoan species mainly affects animals up to one month old (SANTÍN et al., 2008; DEL COCO et al., 2014; OUAKLI et 
al., 2018). A similar situation was observed, who analyzed fecal samples of 200 animals (100 calves and 100 cows) aged between two weeks and six months and over 24 months (cows) of 10 dairy farms from the central region of the State of São Paulo. The authors used microscopy technique, enzyme immunoassay, polymerase chain reaction (PCR) and DNA sequencing analysis of the SSUrRNA genes. They also detected only one animal, three months old, positive for C. parvum (PAZ E SILVA et al., 2013). The low prevalence of this Cryptosporidium species can be explained by the fact that the authors used a reduced number of animals, only six, one month old, same situation found in our work. Nevertheless, the occurrence of C. parvum among the positive animals in our study deserves attention since this species is infectious to humans.

The results of $C$. andersoni clearly demonstrates that depending on the region, in addition to other factors, $C$. andersoni may be a prevalent species in calves from four to six months of age when compared to other species. This adds a new age range to the studies that described $C$. andersoni as a prevalent species only in older calves, heifers and adult cattle (SANTÍN et al., 2004). Furthermore, some studies in farms in the state of São Paulo, through molecular techniques, revealed a higher frequency of $C$. andersoni in calves from zero to six months of age (PAZ E SILVA et al., 2013). In addition to the aforementioned similarities of our results for C. parvum with the work of Paz e Silva et al. (2013), these authors identified C. andersoni as the prevalent species in $85.1 \%(23 / 27)$ of the examined calves aging between one day and six months.

The results of a study conducted in Ethiopia by Wegayehu et al. (2016) were similar to those found in our study. The animals were aged between three days and five months. The authors examined 449 fecal samples of crossbred and zebu animals. Using the Ziehl-Neelsen and PCR techniques, a positivity of 9.4\% (42/449) and 15.8\% (71/449), respectively for Cryptosporidium were detected. Similar to our study, C. andersoni was the most prevalent species (76.1\%), and $92.1 \%$ of the animals affected by this species were between three and five months old. Thus, our results confirm that $C$. andersoni is not exclusively associated with older calves and adult animals.

In the group with the highest prevalence, $27.27 \%$ (6/22) for Cryptosporidium (four males and two females), the animals were kept in the same precarious environment and without separation, facilitating the dissemination of this protozoan among them.

Characterization of Cryptosporidium spp. infecting dairy cattle in the Northwest region of the State of São Paulo identified C. andersoni as the most prevalent species, especially in a younger age group different from those described by several authors. The presence of $C$. parvum indicates that the calves of the studied region should be considered as a potential source of zoonotic oocysts.

For the first time in literature, C. felis was identified in cattle in America, which supports other studies carried out in Poland and Spain and shows the presence of Cryptosporidium species in nonnatural hosts feces.

\section{Acknowledgements}

We want to thank Fapesp for the financial support (process number 2012 / 13733-3).

\section{References}

BORNAY-LLINARES, F. J.; SILVA, A. J. da; MOURA, I. N. S., MYJAC, P.; PIETKIEWICZ, H.; KRUMINISLOZOWSKA, W.; GRACZYK, T. K.; PIENIAZEK, N. J. Identification of Cryptosporidium felis in a cow by morphology and molecular methods. Applied and Environmental Microbiology, Washington DC, v. 65, n. 4, p. 1455-1458, 1999.

CARDONA, G. A.; BEGOÑA BAILO, A. L.; CANO, L.; FUENTES, I.; CARMENA, D. Unexpected finding of feline-specific Giardia duodenalis assemblage F and 
Cryptosporidium felis in asymptomatic adult cattle in Northern Spain. Veterinary Parasitology, Amsterdam, v. 209, n. 3-4, p. 258-263, 2015.

DEL COCO, V. F.; CÓRDOBA, M. A.; BILBAO, G.; CASTRO, A. P. A.; BASUALDO, J. A.; FAYER, R.; SANTÍN, M. Cryptosporidium parvum GP60 subtypes in dairy cattle from Buenos Aires, Argentina. Research in Veterinary Science, v. 96, n. 2, p. 311-314, 2014.

DIXON, B.; PARRIGTON, L.; COOK, A.; PINTAR, K.; POLLARI, F.; KELTON, D.; FARBER, J. The potencialfor zoonotic transmission of Giardia duodenalis and Cryptosporidium sp. From beef and dairy cattle in Ontario, Canada. Veterinary Parasitology, Amsterdam, v. 175, n. 1-2, p. 20-26, 2011.

ELLIOT, A.; MORGAN, U. M.; THOMPSOM, R. C. A. Improved staining method for detecting Cryptosporidium oocysts in stools using malachite green. Journal of General and Applied Microbiology, Setagaya-ku, v. 45, n. 6, p. 139-142, 1999.

GONG, C.; CAO, X. F.; DENG, L.; LI, W.; HUANG, X.M.; LAN, J.-C.; XIAO, Q. C.; ZHONG, Z. J.; FENG, F.; ZHANG, Y.; WANG, W. B.; GUO, P.; WU, K. G.; PENG, G.-N. Epidemiology of Cryptosporidium infection in cattle in China: a review. Parasite, Les Ulis, v. 24, n. 1, p. 1-8, 2017.

KVÁČ, M.; HAVRDOVÁ, N.; HLÁSKOVÁ, L.; DAŇKOVÁ, T.; KANDĚRA, J.; JEŽKOVÁ, J.; VÍTOVEC, J.; SAK, B.; ORTEGA, Y.; XIAO, L.; MODRÝ, D.; CHELLADURAI; J. R.; PRANTLOVÁ, V.; MCEVOY, J. Cryptosporidium proliferans n. sp. (Apicomplexa: Cryptosporidiidae): Molecular and biological evidence of cryptic species within gastric Cryptosporidium of mammals. Plos One, San Francisco, v. 11, n. 1, p. 1-24, 2016.

LEARMONTH, J. J.; IONAS, G.; EBBETT, K. A.; KWAN, E. S. Genetic characterization and transmission cycles of Cryptosporidium species isolated from humans in New Zealand. Applied and Environmental Microbiology, Washington DC, v. 70, n. 7, p. 3973-3978, 2004.

MAKATU, M. Y; SOARES, J. A.; MATOS, L. V. S.; COELHO, W. M. D.; MANHOSO, F. F. R.; KANETO, C. N.; BRESCIANI, K. D. S. Perfil dos produtores rurais de dois assentamentos nos municípios de Brejo Alegre e Birigui, Estado de São Paulo. Veterinária e Zootecnia, Botucatu, v. 24, n. 2, 373-383, 2017.

NAKAMURA, A. A.; MEIRELES, M. V. Cryptosporidium infections in birds - a review. Brazilian Journal of Veterinary Parasitology, Jaboticabal, v. 24, n. 3 , p. 253-267, 2015.
OUAKLI, N.; BELKHIRI, A.; LUCIO, A.; KÖSTER, P. C.; DJOUDI, M.; DADDA, A.; KHELEF, D.; KAIDI, R.; CARMENA, D. Cryptosporidium-associated diarrhoea in neonatal calves in Algeria. Veterinary Parasitology: Regional Studies and Reports, Geneva, v. 12, p. 78-84, 2018.

PAZ E SILVA, F. M.; LOPES, R. S.; ARAUJO, J. R.; HIGH, J. P. Identification of Cryptosporidium species and genotypes in dairy cattle in Brazil. Brazilian Journal of Veterinary Parasitology, Jaboticabal, v. 22, n. 1, p. 22$28,2013$.

SANTÍN, M.; TROUT, J. M. Cryptosporidiosis of livestock. In: FAYER, R., XIAO, L. (Ed.). Cryptosporidium and Cryptosporidiosis. Boca Raton: FL CRC Press, 2008. p. 451-483, v. 2.

SANTÍN, M.; TROUT, J. B. M.; XIAO, L.; ZHOU, L.; GREINER, E.; FAYER, R. Prevalence and age-related variation of Cryptosporidium species and genotypes in dairy calves. Veterinary Parasitology, Amsterdam, v. 122, n. 2, p. 103-117, 2004.

SOPWITH, W.; OSBORN, K.; CHALMERS, R.; REGAN, M. The changing epidemiology of cryptosporidiosis in North West England. Epidemiology and Infection, Cambridge, v. 133, n. 5, p. 785-793, 2005.

THOMPSON, J. D.; GIBSON, T. J.; PLEWNIAK, F.; JEANMOUGIN, F.; HIGGINS, D. G. The CLUSTALX windows interface: flexible strategies for multiple sequence alignment aided by quality analysis tools. Nucleic Acids Research, Oxford, v. 25, n. 24, p. 48764882, 1997.

WANG, L.; XUE, X.; LI, J.; ZHOU, Q.; YU, Y.; DU, A. Cryptosporidiosis in broiler chickens in Zhejiang Province, China: molecular characterization of oocysts detected in fecal samples. Parasite, Les Ulis, v. 21, n. 36, p. 1-5, 2014.

WEGAYEHU T.; KARIM, R.; ANBERBER, M.; ADAMU, H.; ERKO, B.; ZHANG, L.; TILAHUN, G. Prevalence and genetic characterization of Cryptosporidium species in dairy calves in Central Ethiopia. Plos One, San Francisco, v. 11, n. 5, p. 1-11, 2016.

XIAO, L. Molecular epidemiology of cryptosporidiosis: an update. Experimental Parasitology, v. 124, n. 1, p. 8089, 2010.

XIAO, L.; LIMOR, J.; MORGAN, U. M.; SULAIMAN, I. M.; THOMPSON, R. C. A.; LAL, A. A. Sequence differences in the diagnostic target region of the oocyst wall protein gene of Cryptosporidium parasites. Applied and Environmental Microbiology, Washington DC, v. 66, n. 12 , p. 5499-5502, 2000. 